\title{
Alcohol and tax — time for real reform
}

\section{Alcohol tax reform would reduce harm and costs - and could fund major prevention and treatment programs}

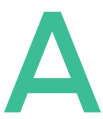

ustralia's first comprehensive report on drugs was entitled Drug problems in Australia - an intoxicated society? This 1977 report from the Senate Standing Committee on Social Welfare noted that alcohol "now constitutes a problem of epidemic proportions". The Committee concluded that, given the extent of the problem, "any failure by governments or individuals to acknowledge that a major problem — and potential national disaster - is upon us would constitute gross irresponsibility".

Many of the report's recommendations are as valid now as they were four decades ago, particularly in relation to alcohol advertising (including the "appeal to sportsmen and sportswomen throughout Australia not to lend their names and prestige to the promotion of alcoholic beverages"), effective controls on availability of alcohol, and use of pricing mechanisms to reduce alcohol use and harm.

It has become increasingly clear that in dealing with harm from alcohol, price matters. There is now an overwhelming consensus from leading Australian and international health authorities and researchers that alcohol taxation is one of the most effective policy interventions to reduce problems related to alcohol. ${ }^{2}$ The World Health Organization has identified alcohol tax increases as a "best buy" intervention in reducing harmful alcohol use. ${ }^{3}$ Even small increases in the price of alcohol can have a significant impact on consumption and harm at the population level. However, alcohol taxation and other pricing strategies have been underused in Australia as a component of the comprehensive approach required to reduce harm from alcohol.

At a time when tax reform is high on the political agenda, there is near-universal agreement that the current approach to alcohol taxation in Australia is complex and that change is long overdue. The Henry Tax Review described the alcohol tax system as "incoherent" and the Wine Equalisation Tax (WET) in particular as "not well suited to reducing social harm". ${ }^{4}$ Others have described the system less flatteringly. Some 16 different excise categories apply, depending on the type and volume of alcohol and container size. Taxes on spirit products are at the upper end of the scale; draught beer taxes are at the lower end. Wine is treated differently; the WET is based on the wholesale price of wine, not its alcohol content. The WET is why cask wine can be promoted and sold for as little as 18 cents per standard drink, or $\$ 1.80$ per litre - cheaper than many bottled waters contributing only 5 cents per standard drink in tax. The system is further complicated by producer rebates and concessions, some of which are no longer appropriate, such as the WET rebate. The WET is

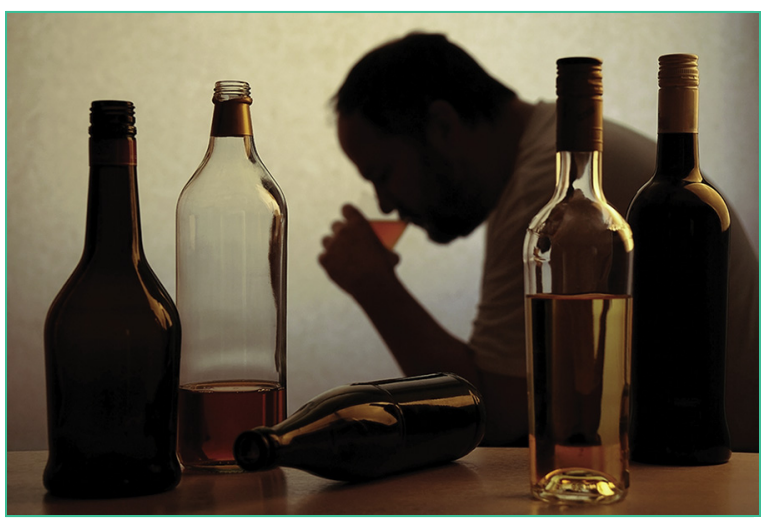

effectively a subsidy, propping up the production of low-value wines.

Health groups are in broad agreement about the key principles that should guide tax reform if the alcohol tax system is to play a more effective role in reducing harm and promoting a lower-risk drinking culture. Approaches to alcohol tax and price should reflect that alcohol is no ordinary commodity and is associated with substantial health and social costs. A volumetric approach that applies to all alcohol products should be central to reform, with tax increasing for products with higher alcohol volumes. ${ }^{5}$ A tiered system that includes stepped increases in tax rates would provide economic incentives for the production and consumption of lower-strength alcohol products and help ensure that the prices of some other products do not drop substantially. ${ }^{6}$

A minimum floor price set at an appropriate level would support and complement a volumetric approach, in particular by targeting the heaviest drinkers who consume the most. A minimum price would restrict the ability of alcohol retailers to heavily discount products, thus undermining the tax strategy, and has been strongly supported by groups concerned about alcohol-related problems in Aboriginal communities.'

BA(Hons), HonDSci ${ }^{12}$

Julia Stafford BPsych(Hons) $)^{2}$

1 Faculty of Health Sciences, Curtin University, Perth, WA.

2 McCusker Centre for Action on Alcohol and Youth, Curtin University, Perth, WA.

m.daube@curtin.edu.au

doi: 10.5694/mjal6.00022

Online first 29/03/16
Other important principles include: there should be an overall increase in alcohol tax collected; the real price of alcohol should increase over time; and changes to the tax system should not decrease the price of alcohol products, other than for low-alcohol products.

In contrast to the consensus among health groups, the alcohol industry is deeply divided on the best approach to alcohol taxation. Arising from the existing variation in excise levels between product categories, the commercial interests of the wine, beer and spirits industries do not necessarily align in relation to tax reform. There is even division within specific industry groups; for example, between premium wine producers and high-volume, 
low-value wine producers. In its submission responding to the government's March 2015 Tax discussion paper, the Winemakers' Federation of Australia (WFA) noted that "Consultation with industry has confirmed mixed views on the optimal tax platform for the Australian wine sector... As such, WFA does not hold a position on the preferred structure for wine tax" ${ }^{\prime 8}$ WFA did, however, affirm that the industry agreed on its opposition to both increasing the level of wine tax revenue and reforms driven by social policy objectives. The divisions between and within industry groups are expected to add to the challenges for government in navigating the range of interests and objectives associated with alcohol tax reform.

Alcohol consumption patterns in Australia are very different now to those in earlier decades, when beer was king, Australian-owned companies dominated and hotels were the drinking venues of choice. Now, beer is in decline (in 2013-14, beer contributed $41.3 \%$ of the total alcohol available for consumption, wine $37.5 \%$, spirits $12.6 \%$ and ready-to-drink pre-mixed beverages $6.3 \%$ ), ${ }^{9}$ most of the major alcohol companies are overseas-owned, and some $80 \%$ of alcohol is sold from retail outlets, primarily chain stores.

There are some encouraging trends, particularly among adolescents ${ }^{10}$ — but alcohol remains pre-eminent as a cause of preventable social and community harm. While the tragedies arising from city-centre violence and road crashes attract regular media coverage, there is also increasing community understanding of alcohol's many hidden and longer-term harms: from domestic violence to cancers, from fetal alcohol spectrum disorder to damage to the developing brains of young drinkers.

As ever in public health, there are no simple, short-term solutions. As is so often the case when profitable products are involved, there is strong, well funded and often misleading resistance to effective action. There is, however, good evidence to support implementation of a comprehensive approach — with carefully implemented tax reform at the forefront. ${ }^{6}$

One additional reform to the alcohol tax system could bring profound benefits to the community. Around the country, alcohol treatment and support services are stretched, funding for prevention is barely visible, and the latest Australian Institute of Health and Welfare expenditure report shows that in the 2013-14 financial year, all public health attracted $\$ 2.22$ billion — an almost derisory $1.5 \%$ of total health funding. ${ }^{11}$

The federal government derives over $\$ 8$ billion annually from the taxes and excise duties levied on alcohol. ${ }^{5}$ In addition to health and social harm, the annual costs of alcohol to the economy are estimated at upwards of \$15 billion. ${ }^{12}$ Further, the government's annual revenue includes more than $\$ 200$ million from underage drinkers and almost $\$ 2$ billion from drinkers under the age of 25 years. $^{13}$

Historically, Treasuries are not keen on hypothecated taxes, but there are good precedents, ${ }^{14}$ notably for tobacco where, in the days of state tobacco licence fees, tax
"It has become increasingly clear that in dealing with harm from alcohol, price matters" increases were successfully used to fund public education and to replace tobacco sponsorship of sport, as well as to provide governments with additional revenue for their general programs.

Many reports in recent decades have recommended additional funding for alcohol prevention and services, both for the community overall and for specific priority groups. A 2015 report commissioned by the Foundation for Alcohol Research and Education concluded that: "By removing the privileged treatment of wine, the government could receive increased revenues in the order of $\$ 1$ billion each year". ${ }^{15}$ Even half of this would enable the establishment of a dedicated National Alcohol Prevention, Treatment and Services Program that could make Australia a world leader in reducing alcohol harm, to match its record in tobacco control.

Such a program would enable the government to provide desperately needed funding for national and local services, to work with and support Aboriginal and other communities in their efforts, and to develop a comprehensive approach to prevention. The funding would enable establishment of a major research-based national public education program, along the lines of the successful 1990s National Tobacco Campaign, as well as better support for enforcing current legislation (including sales to minors), independent controls on alcohol marketing, development of research-based warning label messages, and a range of further national and local activities.

The arguments in favour of alcohol tax reform linked to increased funding for prevention and services are that this will reduce direct and indirect harm, will reduce costs to the health and law enforcement systems and to the community, and will bring special benefits for young people and disadvantaged communities.

The arguments against reform will come from the powerful and massively funded alcohol industry and its allies, which will support the continuation of ineffective policies and oppose anything that might have a serious impact on alcohol use - and hence on alcohol harm.

At a time when there is continuing community and political concern about the impacts of alcohol, broad election policies are being developed and tax reform is under discussion with assurances that "all options are on the table", ${ }^{16}$ there is an opportunity for health groups to press for comprehensive policies that include a clear commitment to alcohol tax reform. This will require strong and consistent communication of the substantial evidence base for reforming alcohol tax to improve health, as well as appropriate responses to misinformation likely to come from vested interests.

Failure by governments to act will now, as 40 years ago, "constitute gross irresponsibility".

Competing interests: No relevant disclosures.

Provenance: Commissioned; externally peer reviewed.

(c) 2016 AMPCo Pty Ltd. Produced with Elsevier B.V. All rights reserved.

References are available online at www.mja.com.au. 
1 Senate Standing Committee on Social Welfare. Drug problems in Australia - an intoxicated society? Report from the Senate Standing Committee on Social Welfare. Canberra: Australian Government Publishing Service, 1977. http://apo.org.au/files/Resource/PolicyHistory_ DrugProblemsInAustraliaAnIntoxicatedSociety. pdf (accessed Dec 2015).

2 Anderson P, Chisholm D, Fuhr DC. Effectiveness and costeffectiveness of policies and programmes to reduce the harm caused by alcohol. Lancet 2009; 373: 2234-2246.

3 World Health Organization and World Economic Forum. From burden to "best buys": reducing the economic impact of noncommunicable diseases in low- and middle-income countries. Geneva: World Economic Forum, 2011.

4 Henry K, Chair. Australia's Future Tax System Review Panel. Australia's future tax system: report to the Treasurer. Canberra: The Treasury, 2010.

5 Doran CM, Byrnes JM, Cobiac LJ, et al. Estimated impacts of alternative Australian alcohol taxation structures on consumption, public health and government revenues. Med J Aust 2013; 199: 619-622. https://www.mja.com.au/journal/ 2013/199/9/estimated-impacts-alternative-australian-alcoholtaxation-structures-consumption

6 National Preventative Health Taskforce. Australia: the healthiest country by 2020 . National Preventative Health Strategy - the roadmap for action. Canberra: Commonwealth of Australia, 2009.

7 The Central Australian Aboriginal Congress Aboriginal Corporation. Submission to Legislative Assembly of the Northern Territory: Select Committee on Action to Prevent Foetal Alcohol Spectrum Disorder. 9 June 2014. http://www.nt. gov.au/lant/parliamentary-business/committees/fasd/ Submissions/Submission_Number_24_Central_Australian_ Aboriginal_Congress.pdf (accessed Feb 2016).
8 Winemakers' Federation of Australia. Submission to the Australian Government's Review of Taxation. 29 May 2015. http://bettertax.gov.au/files/2015/06/Winemakers-

Federation-Australia-Submission-7.pdf (accessed Mar 2016).

9 Australian Bureau of Statistics. Apparent consumption of alcohol, Australia, 2013-2014. Canberra: ABS, 2015 (ABS Cat. No. 4307.0.55.001). http://www.abs.gov.au/ausstats/abs@. nsf/mf/4307.0.55.001/ (accessed Mar 2016).

10 Australian Institute of Health and Welfare. National Drug Strategy Household Survey detailed report: 2013 (Drug Statistics Series No. 28. AlHW Cat. No. PHE 183). Canberra: AlHW, 2014.

1 Australian Institute of Health and Welfare. Health expenditure Australia 2013-14 (Health and Welfare Expenditure Series No. 54. AlHW Cat. No. HWE 63). Canberra: AlHW, 2015.

12 Collins DJ, Lapsley HM. The costs of tobacco, alcohol and illicit drug abuse to Australian society in 2004/05. Canberra: Commonwealth of Australia, 2008. http://www. nationaldrugstrategy.gov.au/internet/drugstrategy/publishing. nsf/Content/mono64/\$File/mono64.pdf (accessed Aug 2009).

13 Li IW, Si J. Alcohol industry and governmental revenue from young Australians. Aust Health Rev 2015; Dec 18 [Epub ahead of print]. doi: 10.1071/AH15146

14 D'Abbs P. Alignment of the policy planets: behind the implementation of the Northern Territory (Australia) Living With Alcohol programme. Drug Alcohol Rev 2004; 23: 55-66.

15 Gilchrist $D$. The goon show: how the tax system works to subsidise cheap wine and alcohol consumption. Canberra: The Australia Institute, 2015.

16 The Hon Kelly O'Dwyer MP. Doorstop interview, Melbourne [transcript]. 1 Nov 2015. http://kmo.ministers.treasury.gov.au/ transcript/063-2015/ (accessed Feb 2016). 